\title{
Variation of Zonal Winds in the Upper Troposphere and Lower Stratosphere in Association with Deficient and Excess Indian Summer Monsoon Scenario
}

\author{
Vazhathottathil Madhu \\ Department of Atmospheric Sciences, Cochin University of Science and Technology, Cochin, India \\ Email: $\underline{\text { madhuv68@gmail.com }}$
}

Received 26 August 2014; revised 18 September 2014; accepted 5 October 2014

Copyright (C) 2014 by author and Scientific Research Publishing Inc. This work is licensed under the Creative Commons Attribution International License (CC BY). http://creativecommons.org/licenses/by/4.0/ c) (i) Open Access

\begin{abstract}
The Indian summer monsoon is one of the most dominant tropical circulation systems in the general circulation of the atmosphere. The country receives more than $80 \%$ of the annual rainfall during a short span of four months (June to September) of the southwest monsoon season. Variability in the quantum of rainfall during the monsoon season has profound impacts on water resources, power generation, agriculture, economics and ecosystems in the country. The inter annual variability of Indian Summer Monsoon Rainfall (ISMR) depends on atmospheric and oceanic conditions prevailed during the season. In this study we have made an attempt to understand the variation of the of zonal winds in the tropical Upper Troposphere and Lower Stratosphere (UT/LS) region during deficient and Excess rainfall years of Indian summer monsoon and its relation to Indian Summer Monsoon Rainfall (ISMR). It is found that in the equatorial Upper Troposphere zonal winds have westerly anomalies during deficient rainfall year's and easterly anomaly during excess rainfall years of Indian summer monsoon and opposite zonal wind anomaly is noted in the equatorial Lower Stratosphere during the deficient and excess rainfall years of Indian summer monsoon. It is also found that the June to September upper troposphere zonal winds averaged between $15^{\circ} \mathrm{N}$ and $15^{\circ} \mathrm{S}$ latitudes have a long-term trend during 1960 to 1998 . Over this period the tropical easterlies and the tropical jet stream have weakened with time.
\end{abstract}

\section{Keywords}

Indian Summer Monsoon, Upper Troposphere/Lower Stratosphere, Zonal Winds 


\section{Introduction}

The lower stratosphere is dynamically linked with the upper troposphere, even though these regions are different. Hence it is necessary to consider the lower stratosphere along with the upper troposphere for better understanding of monsoon dynamics and its variability. Many studies have made an attempt to establish the dynamic role of lower stratosphere and upper troposphere during the monsoon circulation. A major variability in the equatorial lower stratospheric zonal wind with a period of about 26 months was discovered in the 1960s [1]-[3]. These periodic changes of zonal wind to easterly and westerly in the equatorial lower stratosphere became known as Quasi-Biennial Oscillation (QBO). This global oscillation confined to equatorial latitudes occurs simultaneously in both hemispheres. The characteristic feature of the oscillation is its downward phase propagation at a speed of about $1 \mathrm{~km} /$ month [3] [4]. Barbara made an exhaustive study of QBO in the equatorial stratospheric zonal wind [5]. Holton and Tan [6] showed that the QBO is modulating the global circulation at 50 hPa level. Mukherjee et al. [7] using short-period data for an equatorial station to establish the connection between the phases of the QBO in zonal wind in the lower stratosphere $(30 \mathrm{hPa})$ and the percentage of departure of the summer monsoon rainfall of India. They found that strong easterly phase of the QBO was associated with weak Indian monsoon and weak easterly/westerly phase with strong monsoon. They found that $15 \%$ of variability in the summer monsoon rainfall over India is associated with the phase of the QBO. The inter-annual variability of the Indian summer monsoon (June-September) rainfall correlated with the zonal winds at $10 \mathrm{hPa}(30 \mathrm{~km})$ and $30 \mathrm{hPa}(24 \mathrm{~km})$ at Balboa station for the 28-year period (1958-85) concluded that the variations in the zonal wind anomalies at $10 \mathrm{hPa}$ are highly correlated to the monsoon rainfall. And it was found that zonal wind anomalies at $10 \mathrm{hPa}(30$ $\mathrm{km}$ ) lead those at $30 \mathrm{hPa}(24 \mathrm{~km})$ by 6 months, providing a longer lead-time for predicting the Indian monsoon rainfall [8]. Several studies in the past established the link between the stratospheric zonal wind and Indian summer monsoon [9]-[11]. The composite of mean tropopause height for excess and deficient monsoon years showed that all India mean tropopause height is statistically higher in excess monsoon years than the deficient monsoon years [12]. Rajeevan has studied the upper tropospheric circulation and thermal anomalies over the central Asia associated with major drought and floods in India using the upper air data of 21 stations for 22 years (1961-1982) [13]. From their analysis it is observed that significant differences occur between the anomalies during the drought and flood years. Monthly zonal mean wind anomaly for $10 \mathrm{hPa}, 30 \mathrm{hPa}$, and $50 \mathrm{hPa}$ at Balboa an equatorial station $\left(9^{\circ} \mathrm{N}, 80^{\circ} \mathrm{W}\right)$ correlated with the summer rainfall of India for a 29-year period got a correlation of 0.57 [14]. In this paper an attempt has been made to understand the stratospheric and troposphere zonal wind variation with Indian Summer Monsoon Rainfall variability.

\section{Materials and Methods}

We have used the monthly zonal wind (u), meridional wind (v), and temperature (T) from National Center for Environmental Prediction /National Center for Atmospheric Research (NCEP/NCAR) Reanalysis for the present study [15]. This grided binary data set has 144 longitude grids 73 latitude grids $(2.5 \times 2.5$ degree latitude/ longitude) for 17 pressure levels (1000 hPa, 925 hPa, $850 \mathrm{hPa}, 700 \mathrm{hPa}, 600 \mathrm{hPa}, 500 \mathrm{hPa}, 400 \mathrm{hPa}, 300 \mathrm{hPa}$, $250 \mathrm{hPa}, 200 \mathrm{hPa}, 150 \mathrm{hPa}, 100 \mathrm{hPa}, 70 \mathrm{hPa}, 50 \mathrm{hPa}, 30 \mathrm{hPa}, 20 \mathrm{hPa}$, and $10 \mathrm{hPa}$ ). This parameter spans all the region of the UT/LS covering the whole globe. Indian Summer Monsoon Rainfall (ISMR) value has been taken [16] and it is updated up to 1998 from the India Meteorological Department (IMD). Indian Summer Monsoon Rainfall is the average of 306 fixed rain gauge stations from all over India [17]. The long-term normal rainfall (R) for the monsoon season (June to September) is $852.4 \mathrm{~mm}$ and its standard deviation (S) is $84.5 \mathrm{~mm}$. If the $\mathrm{R}_{\mathrm{i}}$ $\geq R+S$ then the year is excess (WET) and $R_{i} \leq R-S$, the corresponding year is deficient (DRY), where $R_{i}$ stands for the rainfall of particular year. Table 1 gives the details of rainfall in $\mathrm{mm}$ and normalized percentage of departure for the monsoon season (June to September) for the study period. The deficient (DRY) and excess (WET) monsoon years chosen for this particular study are also highlighted in Table 1.

\section{Results and Discussion}

\subsection{Vertical Structure of Zonal Wind over the Indian Region}

Figure 1 represent the seasonal variation of zonal wind climatology from 1960 to 1998 averaged over the Indian region $\left(65^{\circ} \mathrm{E}-90^{\circ} \mathrm{E}\right.$ and $\left.0^{\circ}-25^{\circ} \mathrm{N}\right)$ from surface to stratospheric level $(10 \mathrm{hPa})$. The easterly wind prevailed 
Table 1. Indian summer Monsoon Rainfall in mm (ISMR) from 1960 to 1998 and their departure from long-term normal $(852.4 \mathrm{~mm})$ in terms of the standard deviation $(84.5 \mathrm{~mm})$. The normalized percentage of departure for DRY and WET years of monsoon are also marked.

\begin{tabular}{|c|c|c|c|}
\hline YEAR & ISMR (mm) & Normalised Percentage of Departure & DRY or WET \\
\hline 1960 & 839.8 & -0.14 & \\
\hline 1961 & 1020.3 & 1.99 & WET \\
\hline 1962 & 809.8 & -0.5 & \\
\hline 1963 & 857.9 & 0.07 & \\
\hline 1964 & 922.6 & 0.83 & \\
\hline 1965 & 709.4 & -1.69 & DRY \\
\hline 1966 & 739.9 & -1.33 & \\
\hline 1967 & 860.1 & 0.09 & \\
\hline 1968 & 754.6 & -1.16 & \\
\hline 1969 & 831 & -0.25 & \\
\hline 1970 & 938.8 & 1.03 & \\
\hline 1971 & 886.8 & 0.41 & \\
\hline 1972 & 652.9 & -2.36 & DRY \\
\hline 1973 & 913.4 & 0.72 & \\
\hline 1974 & 748.1 & -1.23 & \\
\hline 1975 & 962.9 & 1.31 & WET \\
\hline 1976 & 856.8 & 0.05 & \\
\hline 1977 & 883.2 & 0.36 & \\
\hline 1978 & 909.3 & 0.67 & \\
\hline 1979 & 707.8 & -1.71 & DRY \\
\hline 1980 & 882.8 & 0.36 & \\
\hline 1981 & 852.2 & 0 & \\
\hline 1982 & 735.4 & -1.38 & DRY \\
\hline 1983 & 955.7 & 1.22 & WET \\
\hline 1984 & 836.7 & -0.19 & \\
\hline 1985 & 759.8 & -1.1 & \\
\hline 1986 & 743 & -1.29 & \\
\hline 1987 & 697.3 & -1.84 & DRY \\
\hline 1988 & 961.5 & 1.29 & WET \\
\hline 1989 & 866.7 & 0.17 & \\
\hline 1990 & 908.7 & 0.67 & \\
\hline 1991 & 784.6 & -0.78 & \\
\hline 1992 & 784.9 & -0.78 & \\
\hline 1993 & 896.7 & 0.29 & \\
\hline 1994 & 953 & 1.19 & WET \\
\hline 1995 & 827 & -0.3 & \\
\hline 1996 & 853 & 0 & \\
\hline 1997 & 872 & 0.23 & \\
\hline 1998 & 874 & 0.26 & \\
\hline
\end{tabular}




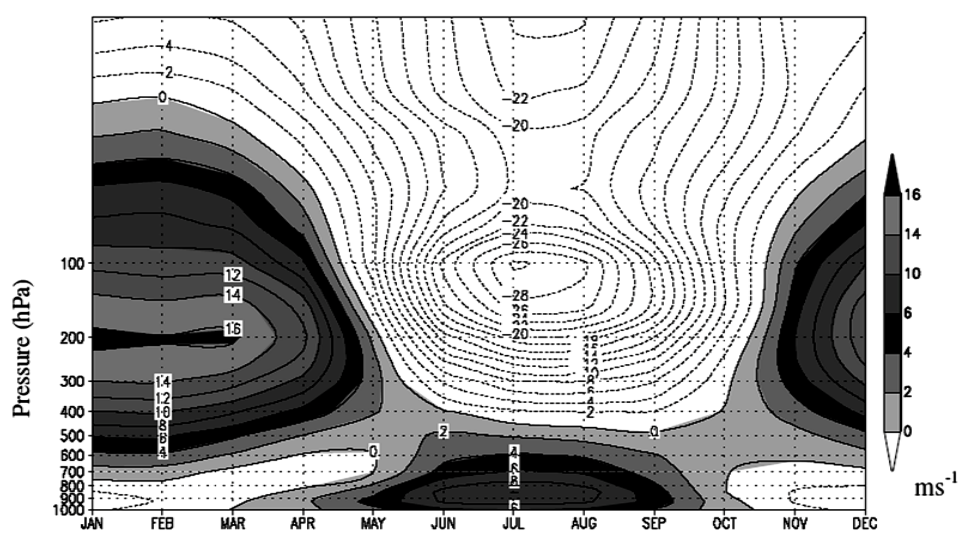

Figure 1. Monthly zonal wind $\left(\mathrm{m} \cdot \mathrm{s}^{-1}\right)$ climatology averaged over the Indian region $\left(65^{\circ} \mathrm{E}-90^{\circ} \mathrm{E} \& 0^{\circ}-25^{\circ} \mathrm{N}\right)$ from surface $(1000 \mathrm{hPa})$ to stratospheric level $(10 \mathrm{hPa})$ for the period 1960-1998.

during October to March up to $850 \mathrm{hPa}$ and gradually disappeared before the monsoon period. The monsoon current (westerly wind) is found to start during March-April and gets strengthened in monsoon period and extends from the surface to $400 \mathrm{hPa}$ level. During November-May, above $850 \mathrm{hPa}$ level the westerly wind prevailed at the lower stratosphere and maximum speed (above $16 \mathrm{~m} \cdot \mathrm{s}^{-1}$ ) is observed around $200 \mathrm{hPa}$. Easterly wind dominates over the entire upper stratosphere throughout the year with a maximum speed of $-24 \mathrm{~m} \cdot \mathrm{s}^{-1}$ during July. The Tropical Easterly Jet stream (TEJ) appears during the monsoon period (June-September) and it reaches maximum speed of $-30 \mathrm{~m} \cdot \mathrm{s}^{-1}$ at $150 \mathrm{hPa}$. During monsoon season the stratospheric easterly and TEJ form a joint easterly wind system at the tropical region of the UT/LS and have maximum value during the northern hemispheric summer (July) which extends to the level of the monsoon current (400 $\mathrm{hPa}$ ). We have made a detailed study in the changes of zonal wind characteristics over the tropical Indian region of the upper troposphere /lower stratosphere (UT/LS) with deficient and excess years of Indian summer monsoons.

\subsection{Wind Anomaly during Deficient and Excess Monsoon Years}

The wind (anomaly) composites for the five deficient (1965, 1972, 1979, 1982 and 1987) and five excess (1961, 1975, 1983, 1988 and 1994) rainfall years of monsoon season are depicted for different pressure levels of UT/LS are presented in Figure 2. It can also be seen that the circulation pattern in the upper troposphere (200 $\mathrm{hPa})$, tropopause level $(100 \mathrm{hPa})$ and lower stratosphere $(70 \mathrm{hPa})$ have considerable changes during the deficient (DRY) and excess (WET) composites over the Indian subcontinent. Both in DRY and WET years of Indian summer monsoons, the lower stratospheric easterly wind prevails in the equator near about $8^{\circ} \mathrm{N}$. But beyond $10^{\circ} \mathrm{N}$, the wind direction becomes nearly opposite from DRY years to WET years. During DRY years (Figure 2(a)) westerlies are found in the Arabian Sea area, have southwesterly in the subcontinent part and southerlies in the Bay of Bengal region. Strong anticyclonic circulation is observed over the Bay of Bengal during DRY years. On the other hand, during WET years (Figure 2(b)) easterlies/south easterlies at Arabian sea, north easterlies over the subcontinent part and northerlies in the Bay of Bengal region. Strong anticyclonic activity is noted in the Arabian Sea region during the excess years of Indian summer monsoon period. The monsoon circulation pattern in the tropopause level at $100 \mathrm{hPa}$ shows out-of-phase relation during DRY and WET years. At $100 \mathrm{hPa}$ the wind is westerly in the entire Arabian Sea, and southwesterly in the land area. Bay of Bengal region, the wind is almost southerly and is cyclonic circulation during the DRY years (Figure 2(c)). In WET years, the wind is northerly beyond $15^{\circ} \mathrm{N}$ and changes to north easterlies to easterlies towards the equator. Intense cyclonic circulation is found over south Bay of Bengal region (Figure 2(d)).

In the upper troposphere (200 hPa), the wind is more or less westerlies in the entire monsoon region during DRY composite. On the other hand, northerly predominates during the WET years. At $200 \mathrm{hPa}$ to $100 \mathrm{hPa}$ the wind must be easterly during the monsoon season due to the appearance of Tropical Easterly Jet (TEJ) stream and it should strengthen during the WET years than in DRY years. Therefore, the wind anomaly pattern obtained for DRY years (Figure 2(c) \& Figure 2(e)) shows the westerly anomalies indicating the weakening of the Tropical Easterly Jet (TEJ) streams. But for the WET years (Figure 2(d) \& Figure 2(f)) the easterly wind anoma- 
a) DRY $70 \mathrm{hPa}$

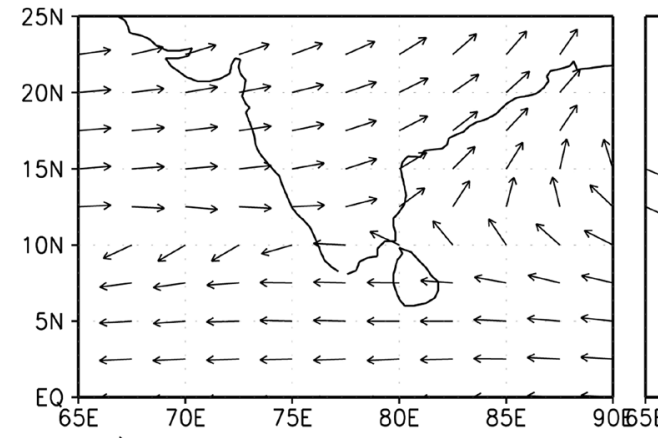

a2) WET - $70 \mathrm{hPa}$

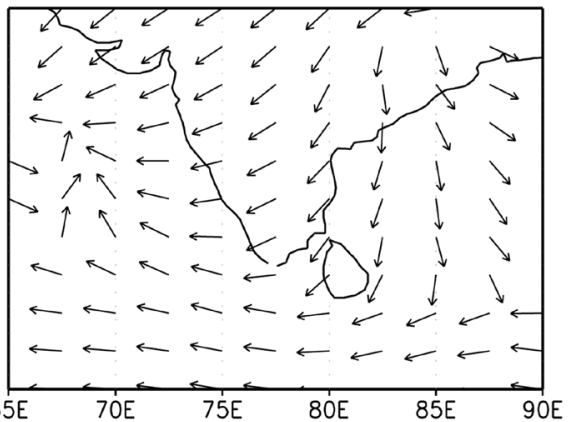

b2) WET - $100 \mathrm{hPa}$
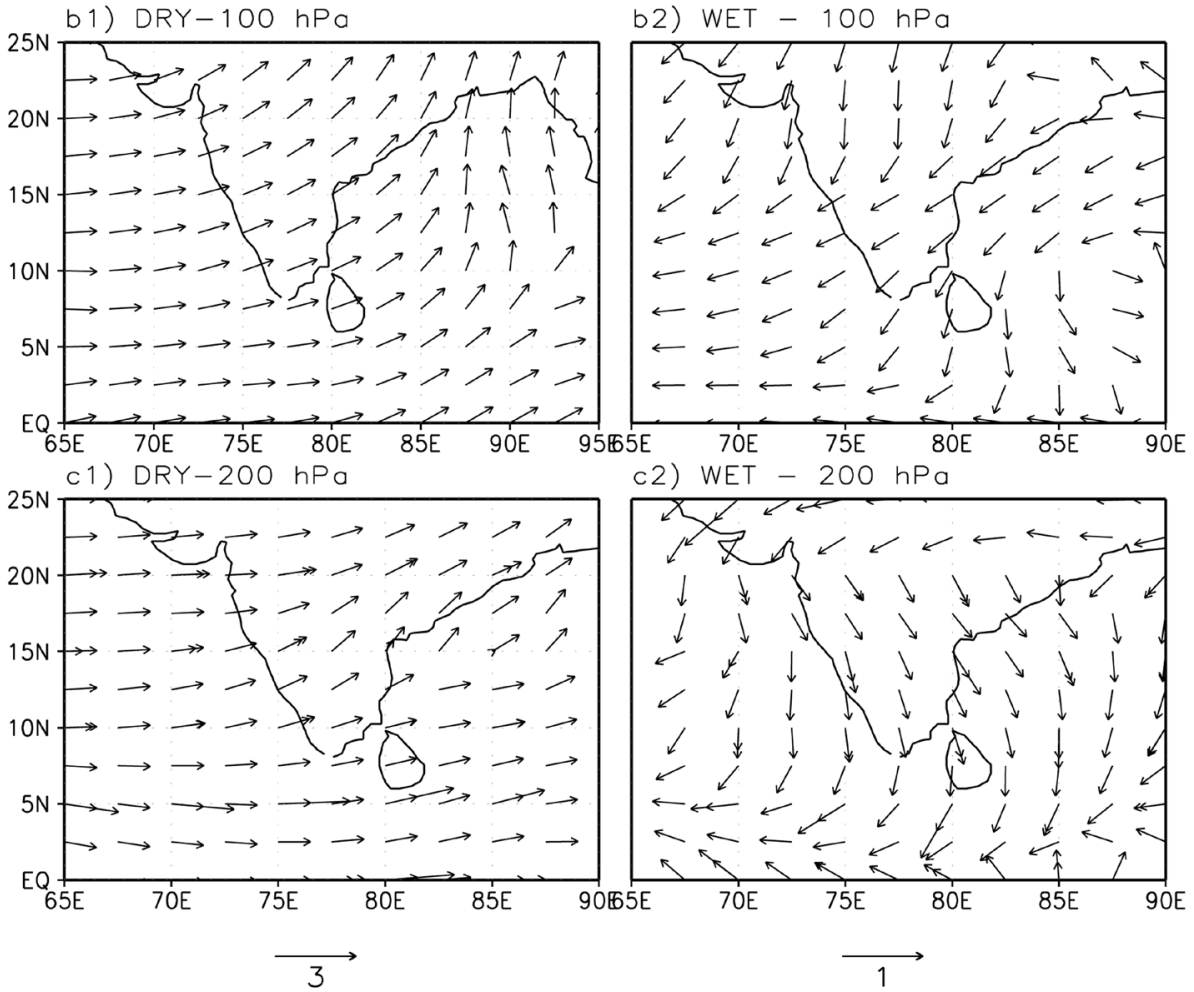

Figure 2. Wind anomaly vector in $\left(\mathrm{m} \cdot \mathrm{s}^{-1}\right)$ over the region $\left(0^{\circ}-25^{\circ} \mathrm{N}\right.$ and $\left.65^{\circ} \mathrm{E}-90^{\circ} \mathrm{E}\right)$ for the levels $70 \mathrm{hPa}, 100 \mathrm{hPa}$ and 200 hPa for DRY (figures a1), b1), and c1)) and WET (figures a2), b2), and c2)) year's composites.

lies show the strengthening of TEJ that represents the Excess (WET) rainfall conditions of Indian summer monsoon.

\subsection{Zonal Wind Composite for Deficient and Excess Years of Monsoon}

We have considered five DRY years (1965, 1972, 1979, 1982, and 1987) and five WET years (1961, 1975, 1983, 1988, and 1994) during the period 1960-1998 for the present study. Figures 3(a) \& Figure 3(b) represent the composite vertical structure of zonal wind for the excess (WET) and deficient (DRY) years averaged for the Indian longitude belt $\left(65^{\circ} \mathrm{E}\right.$ and $\left.90^{\circ} \mathrm{E}\right)$ for the monsoon season (June to September). In Figures 3(a) \& Figure 3(b) it can be seen that on either side of the equator at $200 \mathrm{hPa}$ altitude (upper troposphere region) there exist westerly maxima around $30^{\circ}$ South and $40^{\circ}$ North (the Sub-Tropical Jet stream). In the summer months, flows in both Hadley and Sub Tropical Jet (STJ) streams have weakened; the mean position is further equatorward than the winter position. The southern hemispheric STJ shows the most stable position. This is because the Hadley circulation over the predominantly ocean covered southern hemisphere is more conservative in its geographical behavior than its northern counterpart. Newton and Persson have studied the structural characteristics of the 


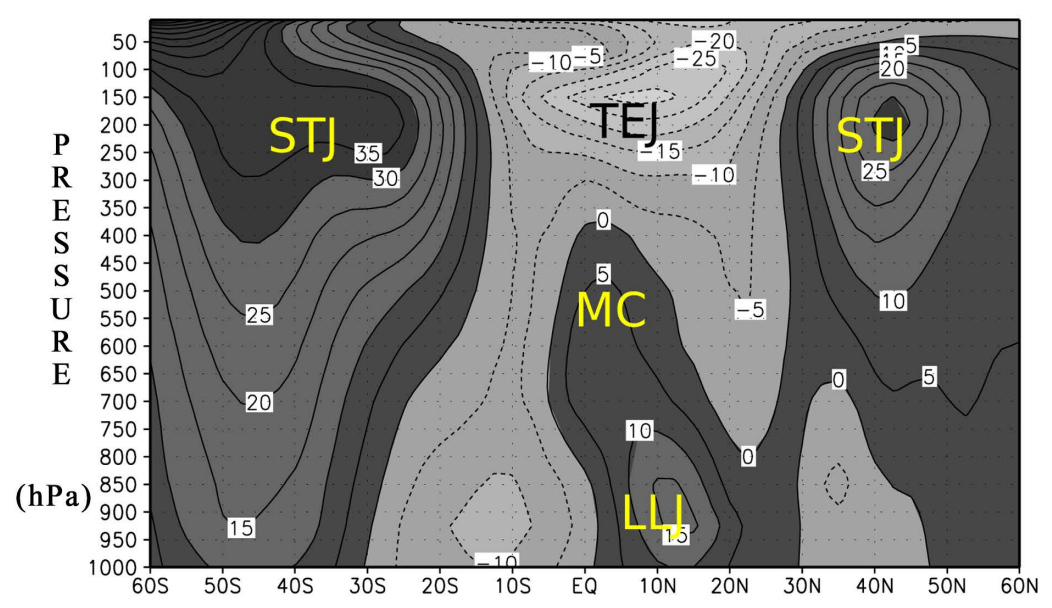

(a)

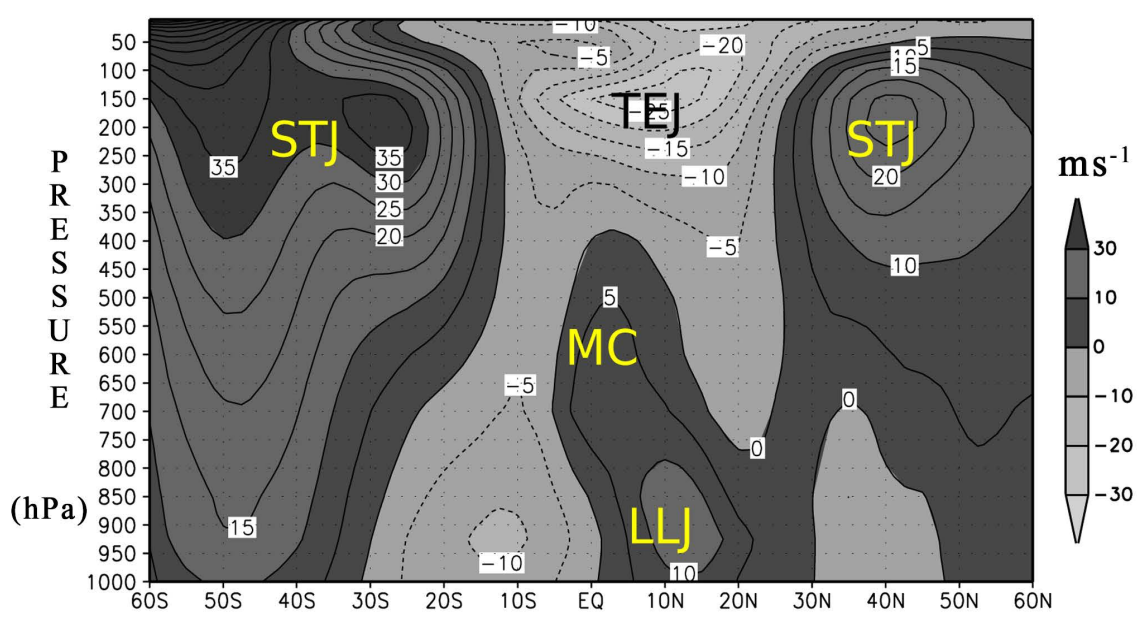

(b)

Figure 3. Vertical variation of zonal wind $\left(\mathrm{m} \cdot \mathrm{s}^{-1}\right)$ for the pressure levels $1000 \mathrm{hPa}$ to10 $\mathrm{hPa}$ averaged over the Indian longitude belt $\left(65^{\circ} \mathrm{E}-90^{\circ} \mathrm{E}\right)$ during monsoon period. The position of Subtropical Jet Stream (STJ), Tropical Easterly Jet Stream (TEJ), Monsoon Current (MC) and Low Level Jet Stream are also marked in the WET year composite (a) and DRY year composite (b).

subtropical jet and certain lower stratospheric wind systems [18]. They found that the mean position of STJ and the year-to-year variability of the westerly wave crests and troughs are important in determining precipitation pattern in the low latitudes. During the Asian summer monsoon a strong easterlies flow of air develops in the upper atmosphere. This upper level easterly wind maximum is identified as the Tropical Easterly Jet (TEJ) with a speed of $28 \mathrm{~m} \cdot \mathrm{s}^{-1}$. Above the Asian summer monsoon current TEJ extends from equator to $20^{\circ} \mathrm{N}$ latitude, at altitudes between 14 to $16 \mathrm{~km}(150 \mathrm{hPa}$ and $100 \mathrm{hPa})$ with its core centered around at $15^{\circ} \mathrm{N}$ [19]. It extends from the China Sea across the Malayan Archeopelago and the Indian Peninsula to Africa. It is maximum developed over the Indian Peninsular region and southeast Arabian Sea overlying the Indian southwest monsoon current. TEJ is found only in the Northern Hemispheric summer (June to September) and it is confined mainly to the Indian Ocean region. The fact that the tropical easterly jet only occurs in the summer season suggests that its development is related to the seasonal cycle of surface heating in the area over which the TEJ lies. As in the case of subtropical jet (STJ), the Tropical Easterly Jet (TEJ) is important for determining rainfall pattern in southern Asia and Africa. At the surface, rainfall has been found to be greatest north of the jet entrance in the southern Asian region and south of the jet exit in the West African region [20]. For the WET composite there is no change in the pattern of wind structure in the upper troposphere and lower stratosphere. But the magnitudes of the westerly (STJ) and easterly (TEJ) jets are much greater in the WET year than that in the DRY years over 
Indian region during the southwest monsoon period. Low Level Jet (LLJ) is also stronger. These results emphasize that the vertical circulation (Hadley cell) is much stronger in the excess (WET) years of monsoon than in the deficient (DRY) years. In the lower troposphere to the north of the equator the westerly Monsoon Current (MC) extended up to the $400 \mathrm{hPa}$ and embedded in the Low Level Jet stream (LLJ) with its core located at 900 $\mathrm{hPa}[21][22]$.

\subsection{A Dipole in Tropical Easterly Zonal Wind in the UT/LS Region}

We observed an interesting phenomenon in the tropical easterly zonal wind in the upper troposphere and lower stratosphere during the summer monsoon period (June to September) having opposite relation with Indian Summer Monsoon Rainfall (A dipole structure). In the lower stratosphere above the TEJ winds are easterly but stronger during deficient (DRY) years than the excess (WET) years of Indian summer monsoon period. This region and Tropical Easterly Jet (TEJ) together form a "UT/LS dipole" pattern whose one pole is stronger during the deficient years and the other in excess years. We identified two vertical boxes, one in the upper troposphere and another in the lower stratosphere in the latitudinal region $15^{\circ} \mathrm{S}$ and $15^{\circ} \mathrm{N}$ of the equator, $200 \mathrm{hPa}$ to $100 \mathrm{hPa}$ in the upper troposphere and $50 \mathrm{hPa}$ to $20 \mathrm{hPa}$ in the lower stratosphere. We call the tropospheric Box as Box A and the lower stratospheric as Box B. The differences in the composites of zonal wind (DRY-WET) fields and temperature composite (DRY-WET) are shown in Figure 4(a) \& Figure 4(b) respectively. The Upper Troposphere/Lower Stratosphere (UT/LS) dipole AB is clearly seen in zonal wind difference above $200 \mathrm{hPa}$. In Figure 4(b) represents the north-south temperature gradient from the equator to $50^{\circ} \mathrm{N}$ latitude. The letters $\mathrm{C}$ and $\mathrm{W}$ represent the regions of the COLD and WARM temperature anomaly. Below a point $150 \mathrm{hPa}$ and above it the north-south temperature gradients are opposite in deep layers (lower stratosphere). Thus in DRY years thermal winds (westerly) are such that TEJ is weaker and the winds of the lower stratosphere are strong easterlies (thermal wind is easterly). It is inferred that the tropopause in this region is lower in DRY years than in WET years of monsoon and it is supported for the Indian region [12].

\subsection{Correlation between UT/LS Zonal Wind and Summer Monsoon Rainfall}

We extracted the zonal wind mean of the two Boxes for the detailed study of the zonal wind in the tropical region occupied by the dipole structure. Winds in the belt $15^{\circ} \mathrm{S}-15^{\circ} \mathrm{N}$ were averaged for levels $50 \mathrm{hPa}$ to $20 \mathrm{hPa}$ (Box B) for the summer monsoon period (June to September) for each year of the period 1960 to 1998. Figure 5(a) \& Figure 5(b) show the averaged zonal wind for the pressure levels $50 \mathrm{hPa}$ to $20 \mathrm{hPa}$ for the longitude region $\left(65^{\circ} \mathrm{E}-90^{\circ} \mathrm{E}\right)$ and for the globe $\left(0^{\circ} \mathrm{E}-360^{\circ} \mathrm{E}\right)$ respectively. There is very little long-term trend in the lower stratospheric zonal wind. The correlation between zonal wind and the summer monsoon rainfall (SMR) is 0.27 for the Indian longitudes belts and a global value of 0.29 during the period of study. These results are significant at 95\% level using Student's t-test. The correlative study of zonal wind and rainfall shows that in the equatorial lower stratosphere deficient (excess) monsoons are accompanied by stronger (weaker) easterly zonal wind (positive correlation), a result in agreement with Mukherjee [7].

Zonal wind in the upper troposphere Box A (200 hPa to $100 \mathrm{hPa}$ ) shows a prominent increasing trend of zonal wind (decreasing easterlies) in the equatorial region during the southwest monsoon period from 1960 to 1998 Figure 6(a) \& Figure 6(b). The correlation between the trend-removed values of the zonal wind in Box A and ISMR is -0.32 for the Indian region and -0.38 for the globe. For the difference between zonal winds (Box B-Box A, which is a measure of the strength of the dipole pattern of zonal wind), the correlation with ISMR is 0.33 for the Indian region and 0.33 for globe. All these correlations are significant at $95 \%$ level.

\subsection{A Possible Mechanism for the Dipole Structure of Zonal Winds in the UT/LS}

Kanamitsu and Krishanamurthi have shown that in a DRY monsoon the tropical easterly jet stream over south Asia and also the upper troposphere easterlies over the global tropics are weaker than normal [23]. Such years have colder upper troposphere over sub-tropical latitudes especially over Asia right from the previous winter as shown by several studies [13]. Accompanying such colder upper troposphere the subtropical westerlies are found to intrude to lower latitudes over south Asia [24]. These colder temperatures persist through the monsoon season affecting the north-south temperature gradient that weakens the tropical easterly jet Figure 4(b). It is seen that this weakening of the north-south temperature gradient is a global phenomenon. Available studies 
(a) ZONAL WIND - (DRY-WET)

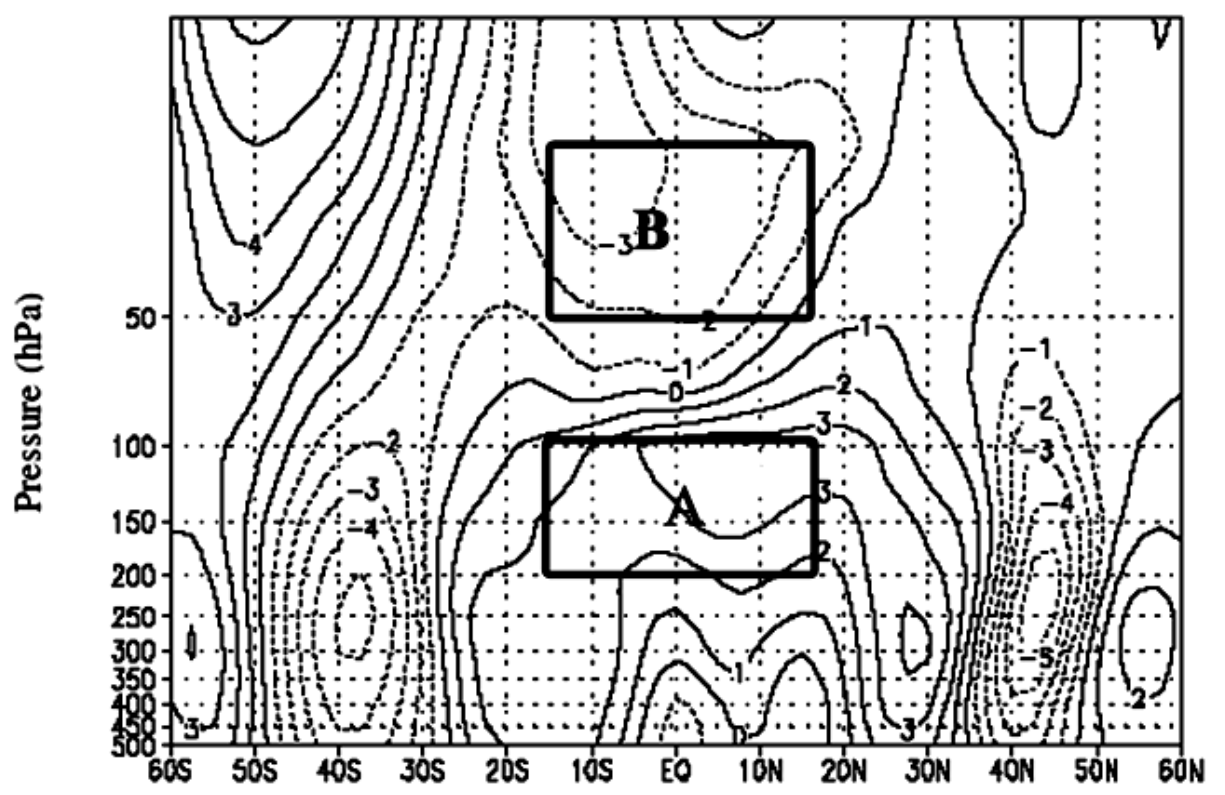

(b) TEMPERATURE - (DRY-WET)

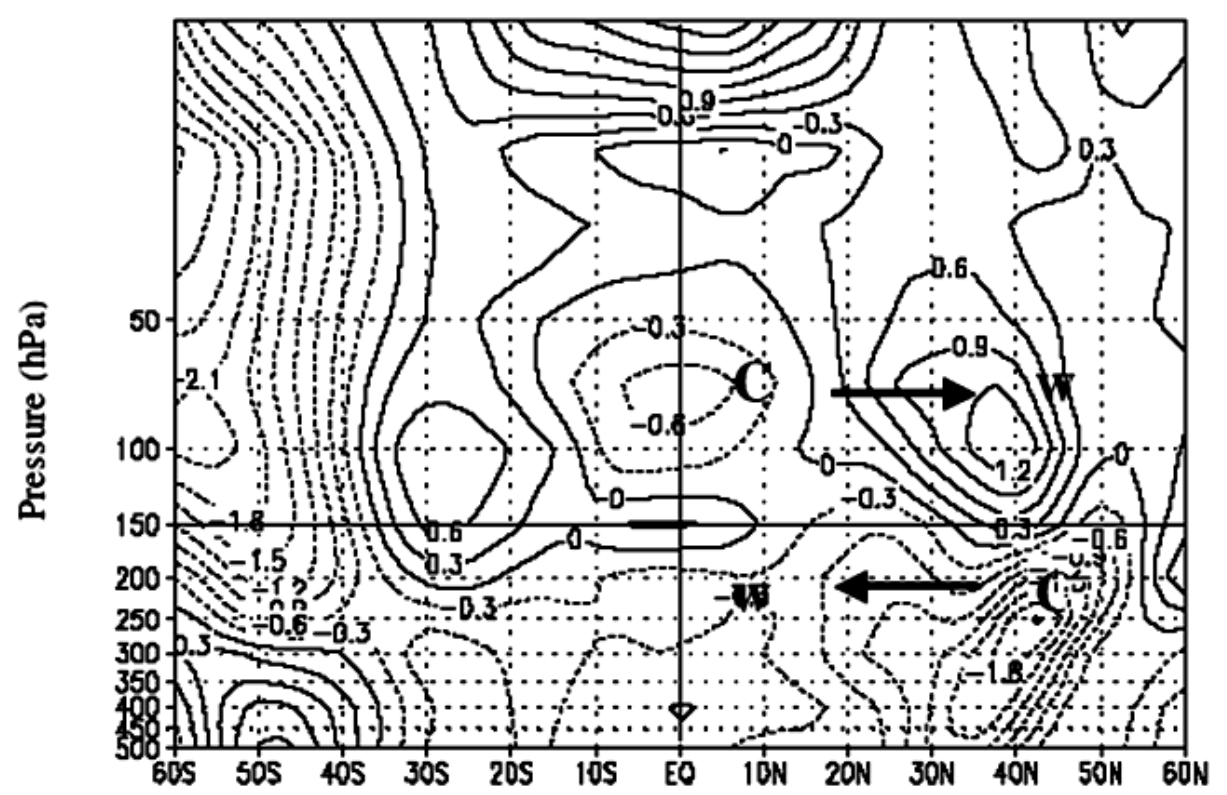

Figure 4. Dipole type of variation in zonal wind $\left(\mathrm{m} \cdot \mathrm{s}^{-1}\right)$ and temperature $\left({ }^{\circ} \mathrm{C}\right)$ variation in the UT/LS region $\left(65^{\circ} \mathrm{E}-90^{\circ} \mathrm{E} \&\right.$ $15^{\circ} \mathrm{N}-15^{\circ} \mathrm{S}$ ) during the Indian Summer Monsoon period (June-September). (a) Upper Tropospheric zonal wind (DRY-WET) in Box A (200 hPa - $100 \mathrm{hPa}$ ) and Lower Stratospheric wind (DRY-WET) in Box B (50 hPa - $20 \mathrm{hPa}$ ); (b) Dipole type of variation in temperature (C-COLD region and W-WARM region) for the same region.

show that in the sub-tropics DRY monsoon has lower tropopause height over India [12]. Since the upper tropospheric cooling in DRY years is a global phenomenon, the sub-tropical tropopause globally over Northern Hemisphere may have a lower height in DRY years compared to WET years. With a lower height for tropopause in DRY years the lower stratosphere should be warmer, which explains the stronger easterlies there. Thus the dipole structure in zonal wind fits in very well with the temperature changes during the summer monsoon period. 


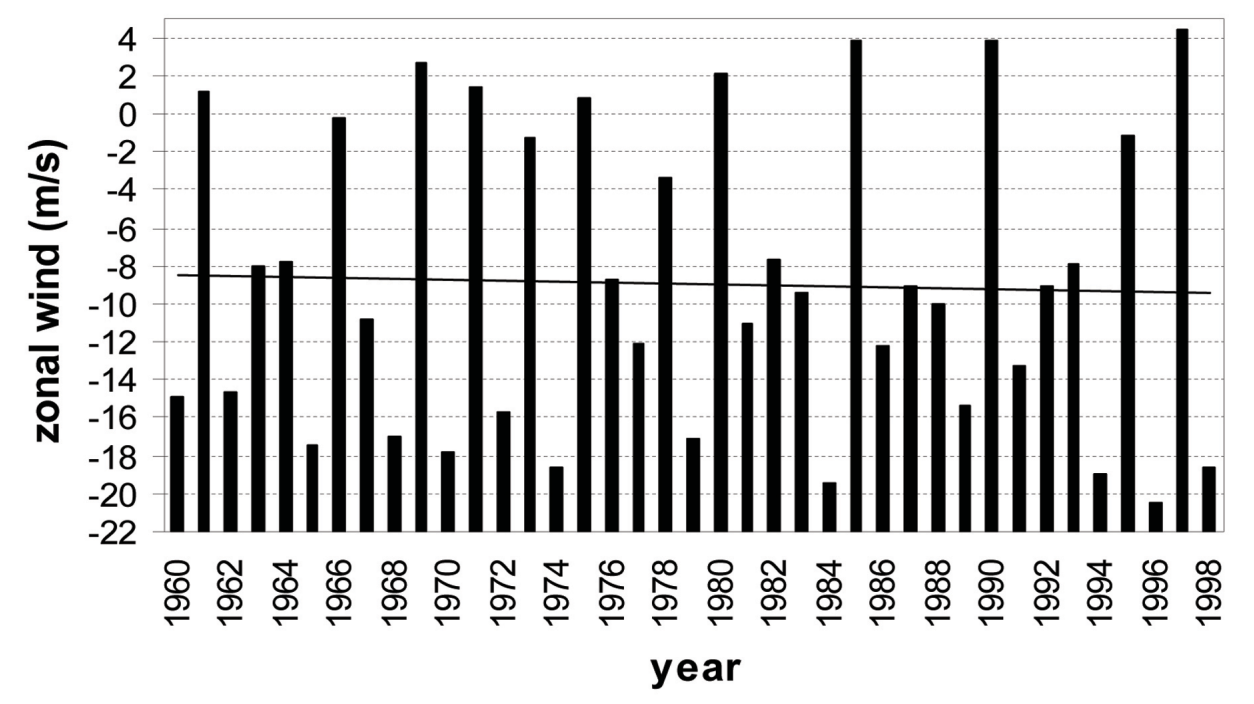

(a)

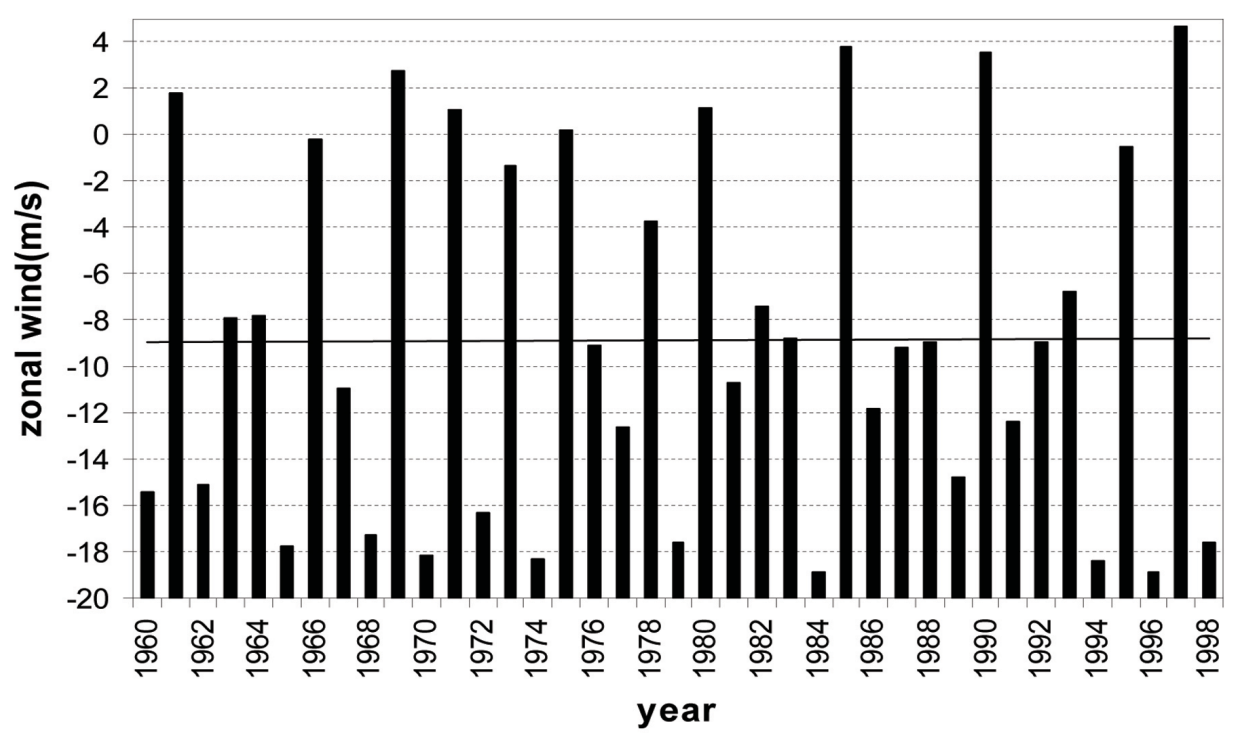

(b)

Figure 5. Zonal wind $\left(\mathrm{m} \cdot \mathrm{s}^{-1}\right)$ in the Box B (Lower Stratosphere $50 \mathrm{hPa}$ to $20 \mathrm{hPa}$ ) averaged over latitude belt $\left(15^{\circ} \mathrm{S}-15^{\circ} \mathrm{N}\right)$ for June to September. (a) Indian region $\left(65^{\circ} \mathrm{E}-90^{\circ} \mathrm{E}\right)$ and (b) Global region $\left(0^{\circ}-360^{\circ}\right)$.

\section{Conclusion}

There are many scientific groups across the country work on the Indian summer monsoon problems to improve forecasting and predictions using different weather forecasting models. In the last two decades, our understanding of monsoon physics and modeling have advanced considerably. Our computational power has also been improved by several orders of magnitude even though the accurate predication and forecast of monsoon is a challenge before whole scientific community due to its high complexity of the problem. In this work an attempt has been made to understand the features of zonal wind in the upper troposphere and lower stratosphere (UT/LS) region over India and over the globe in relation to the strength of the Indian Summer Monsoon Rainfall (ISMR), for the season (June September). In the deficient (DRY) composite upper troposphere winds (tropical easterly jet over South Asia) have westerly anomalies and lower stratospheric winds have easterly anomalies. In excess (WET) years the anomalies are opposite. We have named the Upper Troposphere/Lower Stratosphere (UT/LS) zonal wind anomaly couplet as the "UT/LS Dipole in zonal wind". The intensity of the dipole structure of zonal 


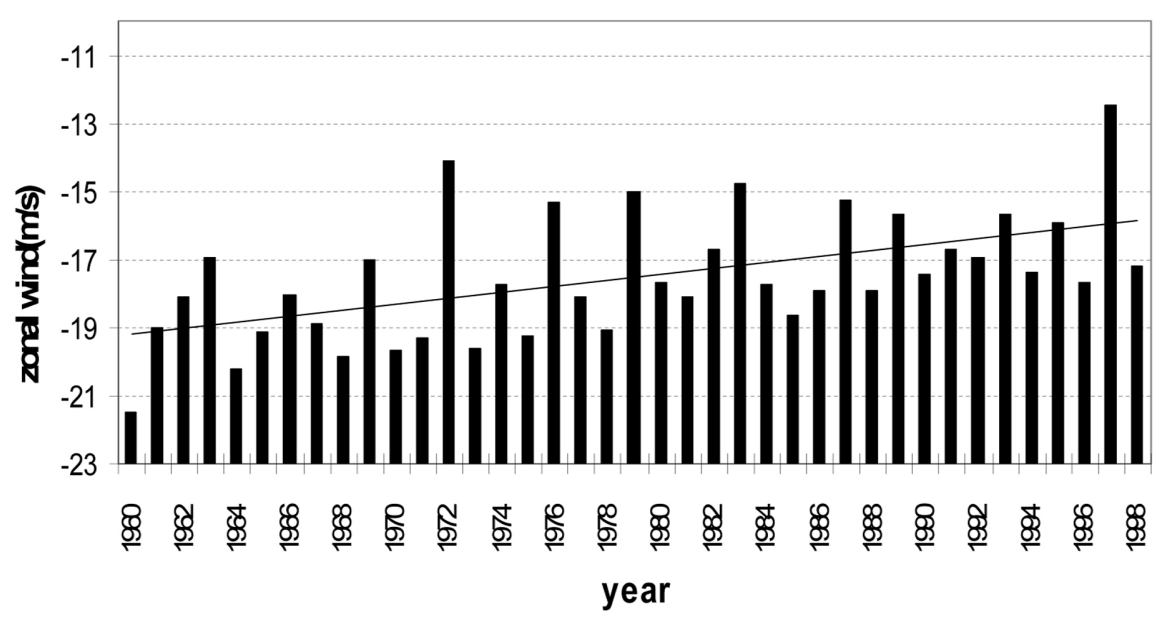

(a)

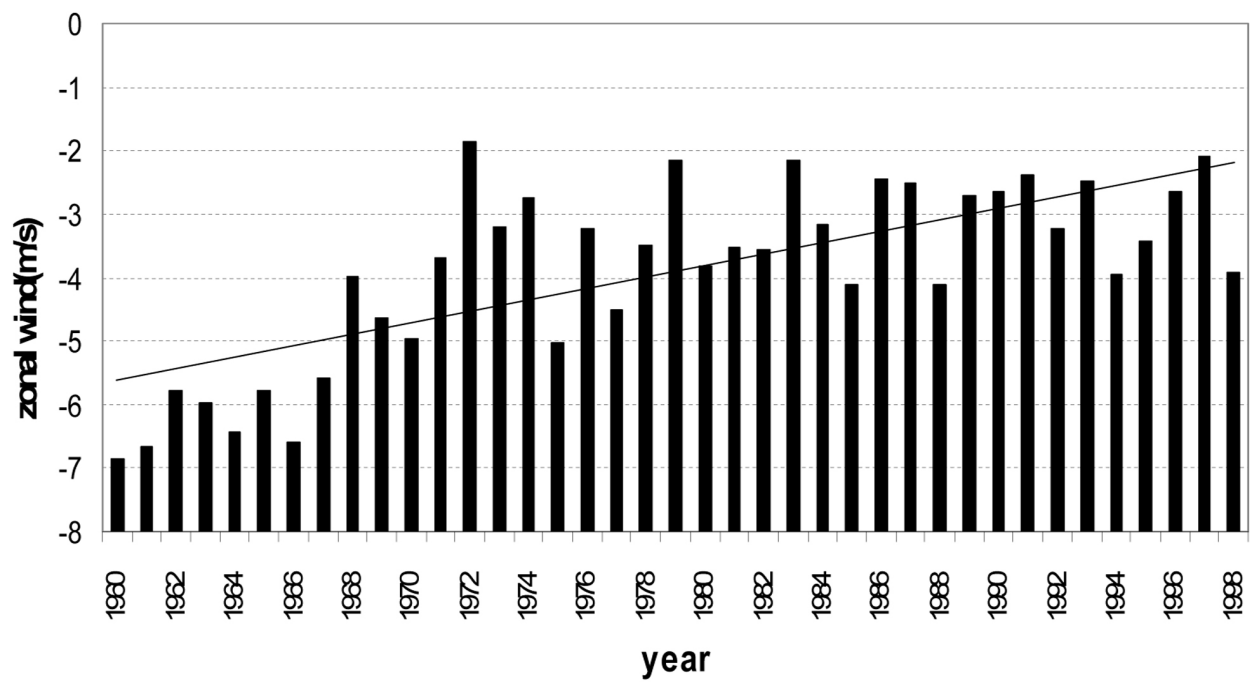

(b)

Figure 6. Zonal wind $\left(\mathrm{m} \cdot \mathrm{s}^{-1}\right)$ in the Box A (Upper Troposphere from $200 \mathrm{hPa}$ to $100 \mathrm{hPa}$ ) averaged over latitude belt ( $15^{\circ} \mathrm{S}$ $\left.15^{\circ} \mathrm{N}\right)$ for June to September. a) Indian region $\left(65^{\circ} \mathrm{E}-90^{\circ} \mathrm{E}\right)$ and b) Global region $\left(0^{\circ}-360^{\circ}\right)$.

wind anomaly is measured as the of lower stratosphere zonal wind anomaly minus the upper troposphere zonal wind anomaly. The correlation between the intensity of the dipole as well as the zonal wind anomalies of upper troposphere and lower stratosphere with ISMR is significant at 95\% level. The upper troposphere of the subtropics of India and northern hemisphere is colder in deficient (DRY) monsoon compared to normal or excess (WET) monsoon. It is assumed that the cold anomaly of DRY years weaken the upper tropospheric easterlies and possibly lower the tropopause, which reverses north-south temperature gradient of the lower stratosphere. The above assumption is the cause for the dipole structure of zonal wind in the UT/LS region of Indian summer Monsoon. It is also evident from the studies that the mean upper troposphere zonal winds of the subtropics over Indian longitude $\left(65^{\circ} \mathrm{E}\right.$ to $\left.90^{\circ} \mathrm{E}\right)$ and over the whole globe $\left(0^{\circ}-360^{\circ}\right)$ between latitudes $15^{\circ} \mathrm{S}$ and $15^{\circ} \mathrm{N}$ (the lower limb of the dipole) are found to be a long-term trend during the period 1960 to 1998 . The tropical easterlies and the tropical easterly jet stream have weakened over this period.

\section{References}

[1] Veryard, R.G. and Ebdon, R.A. (1961) Fluctuations in Tropical Stratospheric Winds. Meteorology Magazine, 90, 125143.

[2] Reed, R.J. (1965) The Quasi-Biennial Oscillation of the Atmosphere between 30 and 50 km over Accention Island. 
Journal of the Atmospheric Sciences, 22, 331-333.

http://dx.doi.org/10.1175/1520-0469(1965)022<0331:TQBOOT>2.0.CO;2

[3] Lindzen, R.S. and Holton, J.R. (1968) A Theory of the Quasi-Biennial Oscillation. Journal of the Atmospheric Sciences, 25, 1095-1107. http://dx.doi.org/10.1175/1520-0469(1968)025<1095:ATOTQB >2.0.CO;2

[4] Quiroz, R.S. (1981) Period Modulation of the Stratospheric Quasi-Biennial Oscillation. Monthly Weather Review, 109, 665-674. http://dx.doi.org/10.1175/1520-0493(1981)109<0665:PMOTSQ>2.0.CO;2

[5] Barbara, N. (1986) An Update of the Observed Quasi-Biennial Oscillation of the Stratospheric Winds over the Tropics. Journal of the Atmospheric Sciences, 43, 1873-1880. http://dx.doi.org/10.1175/1520-0469(1986)043<1873:AUOTOQ>2.0.CO;2

[6] Holton, J.R. and Tan, H.-C. (1980) The Influence of the Equatorial Quasi-Biennial Oscillation on the Global Circulation at 50 mb. Journal of the Atmospheric Sciences, 73, 2200-2208. http://dx.doi.org/10.1175/1520-0469(1980)037<2200:TIOTEQ>2.0.CO;2

[7] Mukherjee, B.K., Indira, K., Reddy, R.S. and Ramana Murty, Bh.V. (1985) Quasi-Biennial Oscillation in Stratospheric Zonal Wind and Indian Summer Monsoon. Monthly Weather Review, 111, 1421-1424. http://dx.doi.org/10.1175/1520-0493(1985)113<1421:QBOISZ>2.0.CO;2

[8] Bhalme, H.N., Rahalkar, S.S. and Sikder, A.B. (1987) Tropical Quasi-Biennial Oscillation of the 10-mb Wind and Indian Monsoon Rainfall-Implications for Forecasting. Journal of Climatology, 7, 345-353. http://dx.doi.org/10.1002/joc.3370070403

[9] Rao, R.K.S. and Lakhole, N.T. (1978) Quasi-Biennial Oscillation and Summer Southwest Monsoon. Indian Journal of Meteorology Hydrology and Geophysics, 29, 403-411.

[10] Mukherjee, B.K., Reddy, R.S. and Rama Murty, Bh.V. (1979) High-Level Warming, Winds and Indian Summer Monsoon. Monthly Weather Review, 107, 1581-1588. http://dx.doi.org/10.1175/1520-0493(1979)107<1581:HLWWAI>2.0.CO;2

[11] Thapliyal, V. (1979) Stratosphere Circulation in Relation to Summer Monsoon over India. Proceedings of Symposia on Hydrological Aspects of Droughts, New Delhi, 3-7 December 1979, 347.

[12] Kulkarni, J.R. and Verma, R.K. (1993) On the Spatio-Temporal Variations of the Tropopause Height over India and Indian Summer Monsoon Activity. Advances in Atmospheric Science, 10, 481-488. http://dx.doi.org/10.1007/BF02656973

[13] Rajeevan, M. (1993) Upper Tropospheric Circulation and Thermal Anomalies over Central Asia Associated with Major Drought and Flood in India. Current Sciences, 64, 244-247.

[14] Sikder, A.B., et al. (1993) Tropical Stratospheric Circulation and Monsoon Rainfall. Advances in Atmospheric Sciences, 10, 379-385.

[15] Kalnay, E., et al. (1996) The NCEP/NCAR 40-Year Reanalysis Project. Bulletin of the American Meteorological Society, 77, 437-471. http://dx.doi.org/10.1175/1520-0477(1996)077<0437:TNYRP >2.0.CO;2

[16] Parthasarathy, B., Munot, A.A. and Kothawale, D.R. (1994) All-India Monthly, and Seasonal Rainfall Series: 18711993. Theoretical and Applied Climatology, 49, 217-224. http://dx.doi.org/10.1007/BF00867461

[17] Parthasarathy, B. (1984) Some Aspects of Large-Scale Fluctuations in the Summer Monsoon Rainfall over India during 1871 to 1978. Ph.D. Thesis, University of Poona, Pune, 370.

[18] Newton, C.W. and Persson, A.V. (1962) Structural Characteristics of the Subtropical Jet Stream and Certain Lower Stratospheric Wind Systems. Tellus, 14, 221-241. http://dx.doi.org/10.1111/j.2153-3490.1962.tb00133.x

[19] Koteswaram, P. (1958) The Easterly Jet Streams in the Tropics. Tellus, 10, 43-57. http://dx.doi.org/10.1111/j.2153-3490.1958.tb01984.x

[20] Hastenrath, S. (1985) Climate and Circulation of the Tropics. D. Reidel, Dordrecht. http://dx.doi.org/10.1007/978-94-009-5388-8

[21] Joseph, P.V. and Raman, P.L. (1966) Existence of Low-Level Westerly Jet Stream over Peninsular India during July. Indian Journal of Meteorology Hydrology and Geophysics, 17, 407-410.

[22] Findlater, J.A. (1969) Major Low-Level Air Current near the Indian Ocean during the Northern Summer. Quarterly Journal of Royal Meteorological Society, 95, 362-380.

[23] Kanamitsu, M. and Krishnamurthy, T.N. (1978) Northern Summer Tropical Circulation during Drought and Normal Rainfall Months. Monthly Weather Review, 106, 331-347. http://dx.doi.org/10.1175/1520-0493(1978)106<0331:NSTCDD>2.0.CO;2

[24] Joseph, P.V. (1978) Sub-Tropical Westerlies in Relation to Large-Scale Failure of Indian Monsoon. Indian Journal of Meteorology Hydrology and Geophysics, 29, 412-418. 
Scientific Research Publishing (SCIRP) is one of the largest Open Access journal publishers. It is currently publishing more than 200 open access, online, peer-reviewed journals covering a wide range of academic disciplines. SCIRP serves the worldwide academic communities and contributes to the progress and application of science with its publication.

Other selected journals from SCIRP are listed as below. Submit your manuscript to us via either submit@scirp.org or Online Submission Portal.
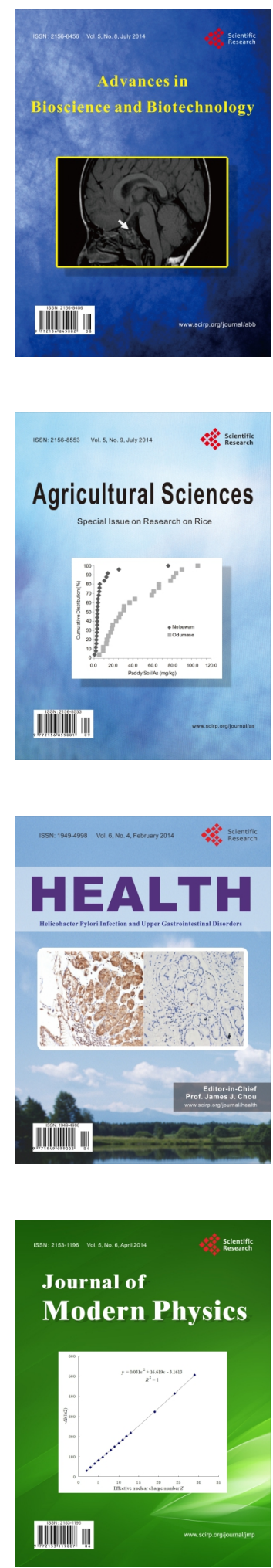
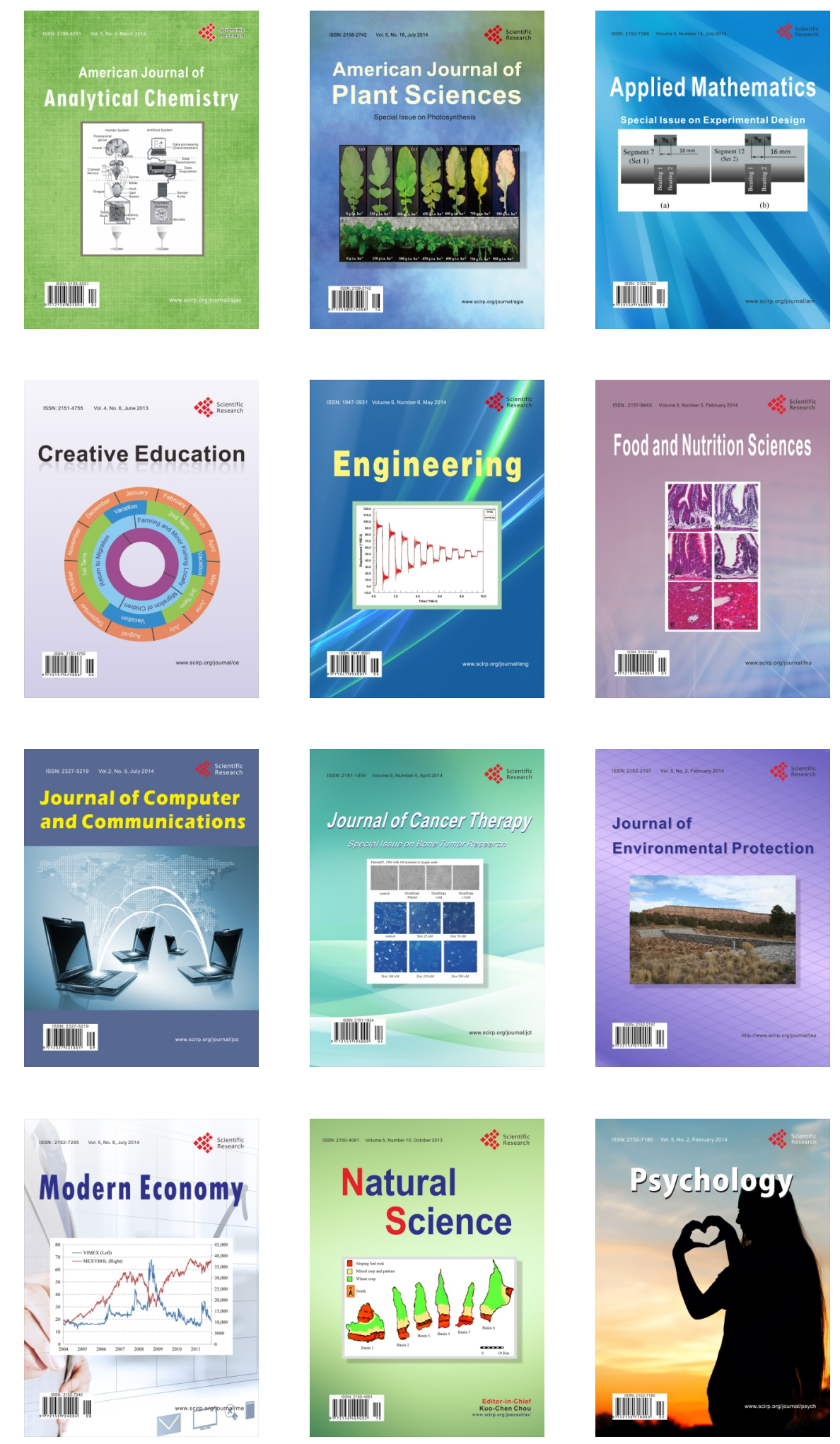